\title{
THE FEASABILITY OF LAND READJUSTMENT FOR INFORMAL AREAS' UPGRADING STRATEGIES IN EGYPT.
}

Asmaa Atef Abdelaziz Ahmed Atta ${ }^{(1)}$, Marwa Abo Elfetouh Elsayed Khalifa ${ }^{(2)}$ Ahmed Sami Abd Elrahman Mohamed Mostafa ${ }^{(3)}$

(1) Post Graduate Student Urban Planning Department, Ain Shams University, Cairo, Egypt.

(2) Professor - Urban Design and Planning, Faculty of Engineering, Ain Shams University, Cairo, Egypt.

(3) Associate Professor - Urban Design and Planning, Faculty of Engineering, Ain Shams, Ain Shams University, Cairo, Egypt.

E-mail Address: asmaa.atef.atta@gmail.com

Mobile number: 01000673246

Qualification: $\quad$ B.Sc. Degree in Architecture Department, Engineering College, Ainshams University, 2012

Current Job: $\quad$ BIM Leader / Project Architect at Saudi Diyar Consultant. 


\begin{abstract}
Urban growth has become a synonymous with informal areas growth in Egypt, Sadly, Informality has become one of the urban and rural areas' characteristics. It is becoming a dire need to provide plan-oriented development projects to change the form or nature of land-use within informal areas to improve public facilities (roads, housing, proper infrastructure, services... etc.) that, accordingly, will promote better housing.

This paper aims to provide a result-based analysis for the Land Readjustment Method (LRM) in Egypt, as an alternative method for urban upgrading strategies with respect to the Egypt's urban / rural policies' settings. It presents an in-depth search and analysis of LRM, as a method that has proved its feasibility in many developed and developing countries. The paper settings take place within a successful Egyptian Case study "El Rezqa Area, Banha, Qalyoubia Governorate, Egypt" that applied LRM in natural policy and institutional Egyptian settings. The project has been carried out by UN-Habitat professionals and volunteers.

The paper relies on a well-established online platform (LR.org) for defining the criterion on which it can be possible to check any urban or rural area and measure how feasible the LR M can be implemented as an upgrading strategy. The paper depends the most on an explanatory approach, where Land Readjustment method then analytical where it comes to the El Rezqa Area as the casestudy where LR has been implemented.
\end{abstract}

\title{
Keywords
}

Land Readjustment Method (LRM), Land Management, Informal Urbanism (IU), Land Use Planning, Land Value, Informal areas 


\section{Table of Contents}

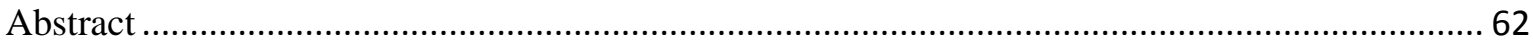

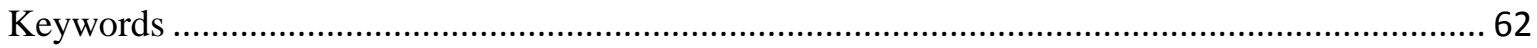

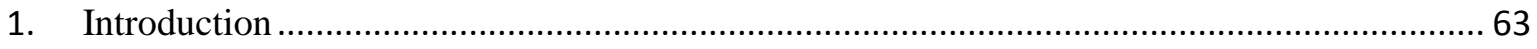

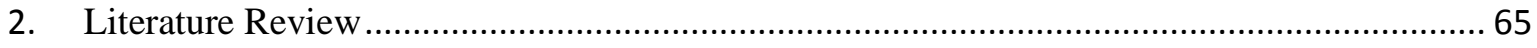

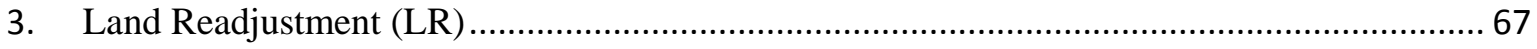

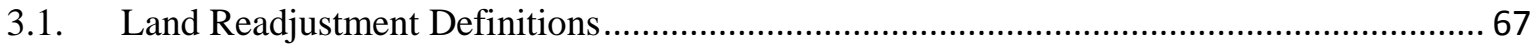

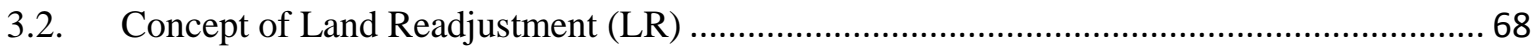

3.3. Illustration for Land Readjustment Method (LR M) application .......................................... 69

4. Practice of Urban Land Readjustment in Egypt ................................................................... 70

5. Land readjustment Online Evaluation Platform (LR.org, 2018) .............................................. 71

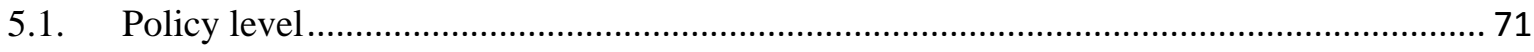

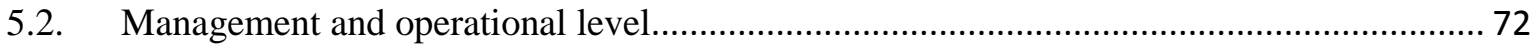

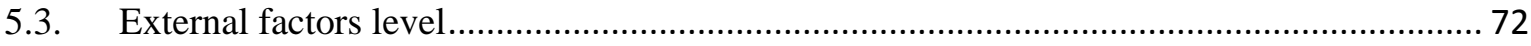

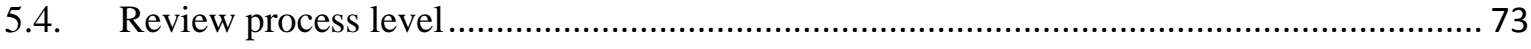

6. Land Readjustment in Egypt (The pilot area: El Rezqa area, Banha) ...................................... 73

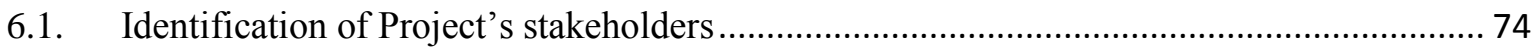

6.2. Identification of landowners and land surveying ......................................................... 74

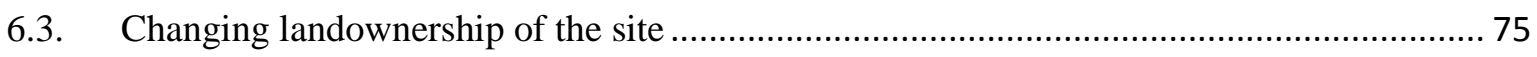

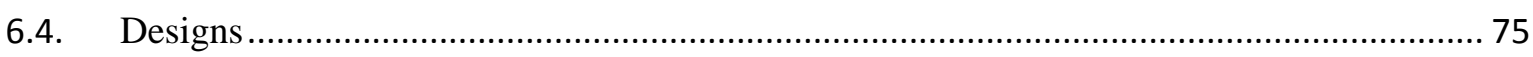

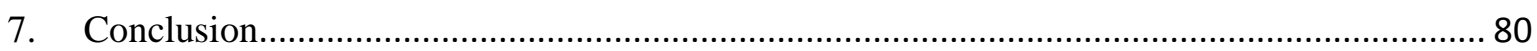

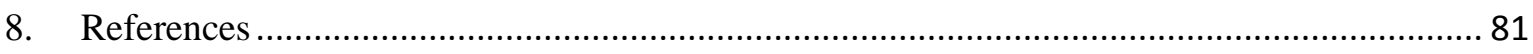

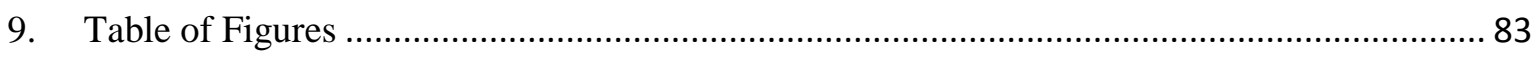

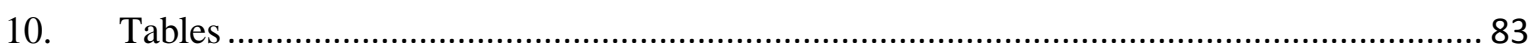

\section{Introduction}

In 1982, the term Land readjustment (LR) was mentioned for the first time by Doeble, "land readjustment has been used for projects in urban areas as their objective was the conversion of rural land to urban building sites or the redevelopment of existing urbanized areas. Since this mechanism has not yet been much discussed in English, it is hoped that land readjustment can become the commonly accepted term" (Doebele, 1982). 
LR is considered as one of the land development tools used in the developing world to support urbanization requirements. It has the ability to solve land-use problems in urban areas when there is a need to redesign and create new urban settlements (Hein, 2010). Land Readjustment (LR) is one of the methods of land development for developing or improving urban infrastructure and enhancing utility and land value, so a LRM is not a land acquisition method, but a kind of land consolidation method, which is called "Land Replotting" (Yomralioglu and Bayram, 1996). LRM features is where; Installing urban infrastructure by means of the land contribution by landowners to be used in public facilities, according to a layout plan and, Financing project costs by means of the land contribution to cover the project's financial costs, where all parcels of land are re-plotted according to a layout and land use plan, accordingly, all land rights are legally transferred to the new re-plots by the land re-plotting disposition will take place (De Souza et al., 2018).

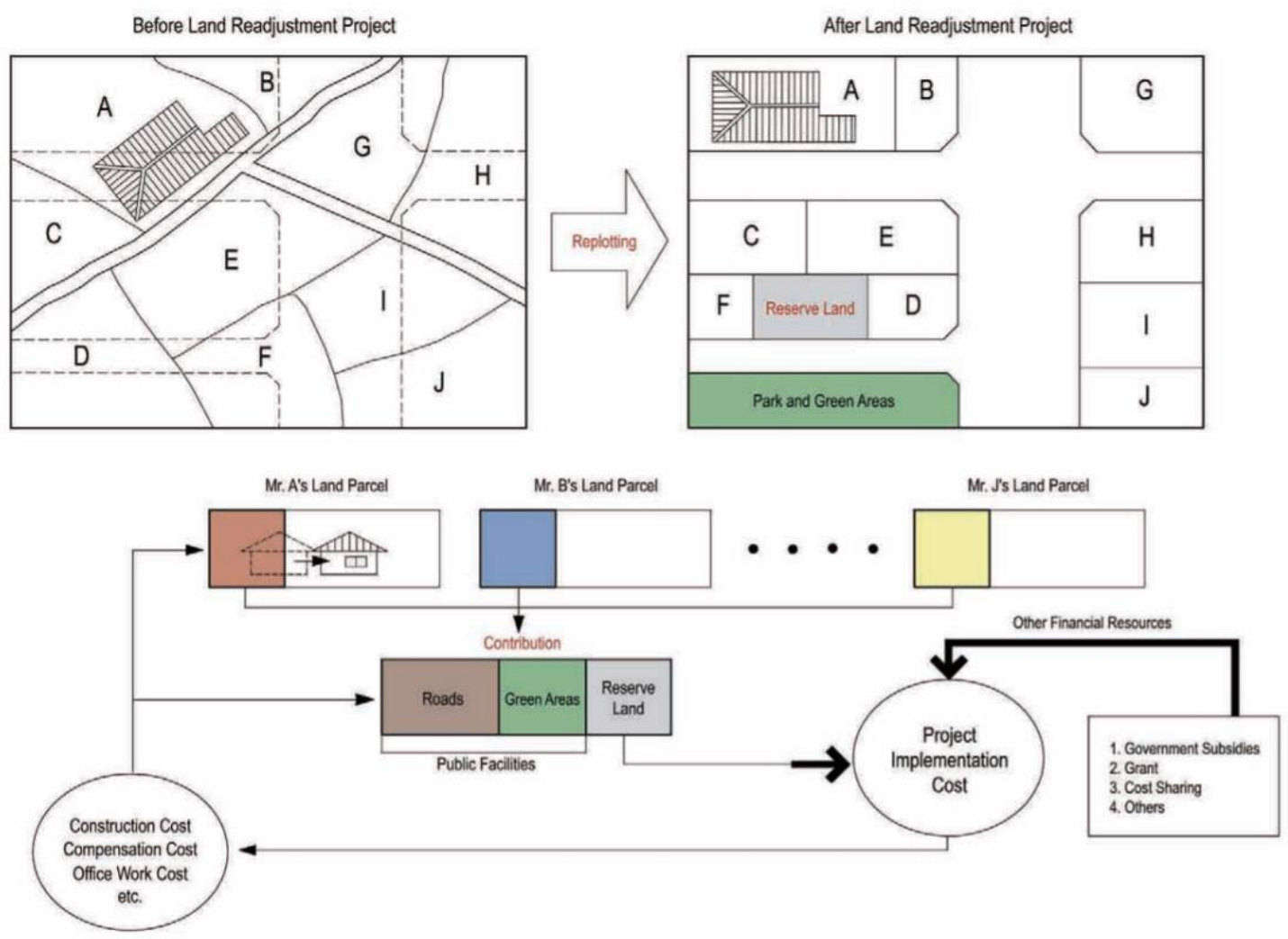

Figure 1, An Illustration of LR Process, (YAU, 2009) 
A common feature of land readjustment is that each property owner typically receives a smaller parcel after readjustment than the one they originally had. Despite the reduction in ownership area, the property may be significantly higher in value than before readjustment because of the higher potential for development given from the new zoning, increased densities, new infrastructure, and new parcel shapes aligned to maximize the planned development. In an urban renewal context, the value distribution may take the form of other types of property, such as units in multi-family housing, rather than as actual parcels (David Sims, 2003; María del Carmen, 1992; Motala, 2002).

On the Theoretical level, a framework will be concluded with reference to the online developed evaluation framework platform (LR.org, 2018), that is based on four main evaluation levels, which are; policy level, management and operational level, external factors level, and review process level.

In 2014, LR M was introduced in Egypt by the UN Habitat Egypt. El Rezqa Area, Banha, Qalyoubia Governorate in Egypt was selected as a pilot project to apply LR M. Since Banha city's expansion was in all directions, mainly in the form of informal settlements on agricultural land. The paper will highlight how feasible LR $M$ was in an Egyptian context. As well as, highlighting LR $\mathrm{M}$ important role in enhancing the planning processes in a controlled and sustainable manner, while, considering the socio-economic benefits driven from the LR M implementation that can be translated into an equitable and efficient urban settlement pattern to measure how LR M was feasible (David Sims, 2003)

\section{Literature Review}

Informal areas respond to economic fundamentals; And as many of us now live in cities which in many cases are hundreds, thousands, of years old. It is an inevitable consequence of the organic and informal nature of the growth of these cities that, from time to time, there is a need to make radical changes to their physical structure if they are to continue to thrive and prosper. However, given the nature of land ownership in most cities in the world - with land being held privately - it is often difficult to make radical changes. Land reassembly for urban development has become a worldwide need (David Sims, 2003; María del Carmen, 1992; Motala, 2002).

There are three land assembly methods for urban development that have been used globally to follow up with these radical urban changes: (Uzun, 2009)

- Voluntary method (Voluntary co-operation between landowners)

- Compensation method (Compulsory purchase by a public authority).

- Land Readjustment Method. 
Between these methods there is of course a wide variety of other detailed ways of getting around the target, but most of the different tools highlight the main concepts of these three approaches which will be illustrated. (Robert Home, 2007; Uzun, 2009; Yomralioglu and Bayram, 1996). The choice of the best method depends on the size of the redevelopment, resources-financial and human-availability and the type of landowners involved while concluding the most appropriate method to follow for the purpose of preventing future informal areas formation.

\section{The current planning processes for city expansion in Egypt}

A key policy instruments used in managing urban expansion of existing cities were highlighted in the Building Law No 119 for the year 2008, these are described below. The policy instruments should be applied in sequence: urban Growth Boundaries (UGB) should be applied first during the process of conducting cities strategic plans.

The goal behind the pilot project is to propose a coping mechanism to combat informal urban expansion by introducing a new approach of planning from below that is able to come up with plans that fit the needs of the local community and correspond to the spatial reality of landownership and as such lead to buildable plots and building permit.

UN-Habitat implemented the Urban Policies, Governance and Legislation Program in Egypt by drawing on the complementary and synergistic roles of its four strategic partners (the Ministry of Housing and Urban Communities, the Ministry of Local Development, the Ministry of Planning and the Ministry of Finance). The programs aim is to enhance the capacity of national and local actors to develop urban polices, and reform the legal and institutional framework governing territorial governance and citizen engagement.

The expected outcomes on the strategic level will include; promoting efficient and decentralized local government; enhancing accountability measures and application of relevant instruments at local and regional government; establishing a planning process mechanism that provides a platform for mobilizing community efforts and participation in implementing developmental projects in cities, while on the community level will include; building the capacities of local communities, local governments, CSO $\mathrm{s}$ and other stakeholders especially in policy analysis, planning and financial management; and increasing dialogue for decision making and strengthening strategic partnerships and collaboration at the national, regional and local levels to enhance the adoption and implementation of relevant urban development polices; promoting youth and women's engagement in the formulation, implementation and monitoring of urban policies. 


\section{Land Readjustment (LR)}

Land Readjustment can offer a land management solution, as it is a tool used to assemble all land parcels in a particular area and re-plan them in a one unit in means of design. It works to provide access to land for public use by capturing a proportion of the value, whether financial or in kind, created by development. Land readjustment is a mechanism that can be used to unlock the intrinsic, but latent, value of land that was previously inhibited by plot fragmentation and land ownership patterns which are incompatible with the optimal use of land.

\subsection{Land Readjustment Definitions}

Regarding to the literature review there were many types of Land Readjustment (LR) definitions, however the paper focuses on online-based and book-based definitions which can be shown in table will be divided into bookbased and internet-based definitions as shown in Table 1;

Table 1, Land Readjustment Definitions (By the Researcher)

\begin{tabular}{|c|c|}
\hline Reference & LR Definitions \\
\hline $\begin{array}{l}\text { (Doebele, 1987; } \\
\text { Van der Molen, } \\
\text { 2015; van der } \\
\text { MOLEN, 2014) }\end{array}$ & $\begin{array}{l}\text { "Process whereby land owners pool their lands and then re- } \\
\text { subdivide the assembled property, setting aside a portion of the total } \\
\text { parcel for improved access and infrastructure and an additional } \\
\text { portion for sale or commercial development to pay for the } \\
\text { improvements to the property" }\end{array}$ \\
\hline $\begin{array}{l}\text { (Hong and } \\
\text { Needham, 2007; } \\
\text { Molen, 2013) }\end{array}$ & $\begin{array}{l}\text { 'Land readjustment gives all affected property owners in a } \\
\text { redevelopment district the power, by majority vote, to approve or } \\
\text { disapprove the transfer of land rights to a self-governing body for } \\
\text { redevelopment; instead of buying out all existing property owners } \\
\text { using eminent domain, the agency invites property owners to } \\
\text { become stakeholders and to contribute their real assets to the project } \\
\text { as investment capital; in return, the agency promises to give each } \\
\text { owner a land site of at least equal value in the vicinity of the original } \\
\text { site upon completion of the redevelopment; after all properties in the } \\
\text { district are assembled, the combined land sites are subdivided } \\
\text { according to a master plan designed and approved by the } \\
\text { stakeholders. }\end{array}$ \\
\hline $\begin{array}{l}\text { (Uzun et al., } \\
\text { 2009) }\end{array}$ & $\begin{array}{l}\text { "Land readjustment (LR) is one of the land development tools used } \\
\text { in the developing world to support urbanization requirements. It has } \\
\text { the ability to solve land-use problems in urban areas when there is a } \\
\text { need to redesign and create new urban settlements" }\end{array}$ \\
\hline (Archer, 1992) & $\begin{array}{l}\text { "Land readjustment/ pooling is a technique for managing the urban } \\
\text { development of urban-fringe lands, whereby a group of separate } \\
\text { land parcels are assembled for their unified planning, servicing and } \\
\text { subdivision as a single estate, with the sale of some of the new } \\
\text { building plots to recover the costs and the redistribution of the other } \\
\text { plots back to the landowners." }\end{array}$ \\
\hline
\end{tabular}




\begin{tabular}{|l|l|}
\hline ("UN Habitat," & $\begin{array}{l}\text { "Under land readjustment programs, undeveloped areas, usually an } \\
\text { urban fringe, can be designated for improvement, including the } \\
\text { rearrangement of plots, the grading of land, the construction of } \\
\text { roads and the provision of infrastructure. Instead of paying a } \\
\text { betterment levy, landholders must surrender part of their land to the } \\
\text { local authority as payment for the improvements. The local } \\
\text { authority can then resell this portion of land to recoup the } \\
\text { improvement costs." }\end{array}$ \\
\hline $\begin{array}{l}\text { World Bank } \\
\text { (Lozano et al. }\end{array}$ & $\begin{array}{l}\text { Land readjustment is an approach that is commonly used in East } \\
\text { Asian countries, such as Japan and the Republic of Korea. In } \\
\text { addition, it has also been used in Germany to enable the assembly } \\
\text { and planning of privately-owned land at the peri-urban fringe, as } \\
\text { well as the delivery of infrastructure and services on such land. } \\
\text { Using this approach, the government pools or assembles the various } \\
\text { privately-owned land parcels in each area and prepares a land use } \\
\text { plan for the overall area including designating spaces for public } \\
\text { infrastructure and services such as roads and open spaces. It then } \\
\text { implements the plan and provides the necessary trunk } \\
\text { infrastructure }{ }^{1} \text {. At the end of the process, the government returns to } \\
\text { each landowner a land parcel proportional to their original parcel } \\
\text { but of smaller size (for instance, 50-60 percent of the original land } \\
\text { parcel) - except that the new land parcel is of a higher value because } \\
\text { it is now serviced urban land. The government retains selected } \\
\text { strategic land parcels that it auctions or sells at market rates for cost } \\
\text { recovery of its investment in infrastructure and service delivery. }\end{array}$ \\
\hline
\end{tabular}

\subsection{Concept of Land Readjustment (LR)}

the basic principle of land readjustment is that property owners within a designated redevelopment area participate in a public-private joint venture where the municipal redevelopment authority (the stakeholders in terms of either governmental or NGOs or Consultancy's representatives who are following up with the selected site's land parcels' owners) will pool, re-plot, and redistribute the land or shares in a common land trust amongst the contributing property owners. The governmental and consultant's representative will work coherently to provide valuable redevelopment rights to the property owners along with the new parcels or shares.

\footnotetext{
${ }^{1}$ Trunk infrastructure: is the 'higher order' or 'shared' development infrastructure required to ensure the healthy and safe functioning of the uses it is servicing. Trunk infrastructure's primary purpose is to service 'catchment' areas with a few users or developments, rather than servicing individual developments or users (The Local Government and Municipal Knowledge Base, 2018)
} 
The property owners may subsequently monetize these assignments through sale of their portion of the property and the associated up-zoned redevelopment rights to developers, and/or by retaining an equity stake in the redevelopment (Brownfields Redevelopment Solutions, Inc., 2014). Land readjustment seeks existing land structure management when a systematic urban land development is required. The main objectives of a land readjustment project are; Development of new urban sites, Redevelopment of an already urbanized area, Improvement and expansion of public facilities, and Disaster rehabilitation.

\subsection{Illustration for Land Readjustment Method (LR M) application}

As in the previous point LR definitions were highlighted, subsequently, for a better understanding the changes that can happen to any pilot area if LR was implemented, shown as follows in figure 1.

\section{BEFORE}

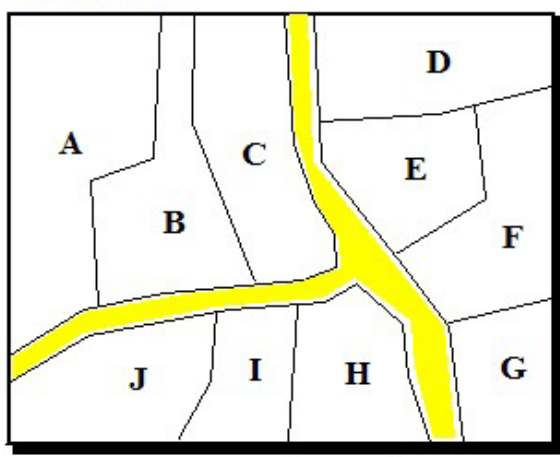

A's old parcel

B's old parcel

J's old parcel
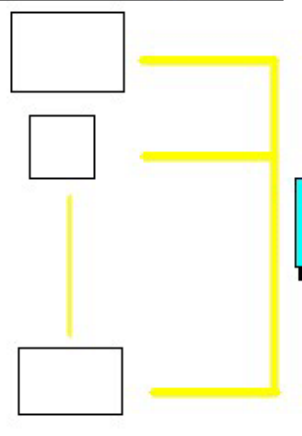

AFTER

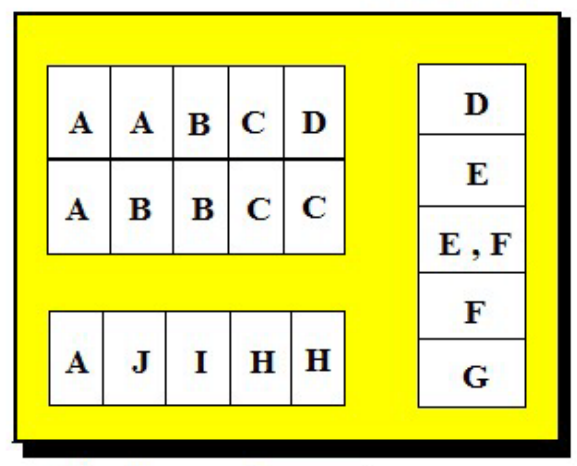

contribution

Public Area

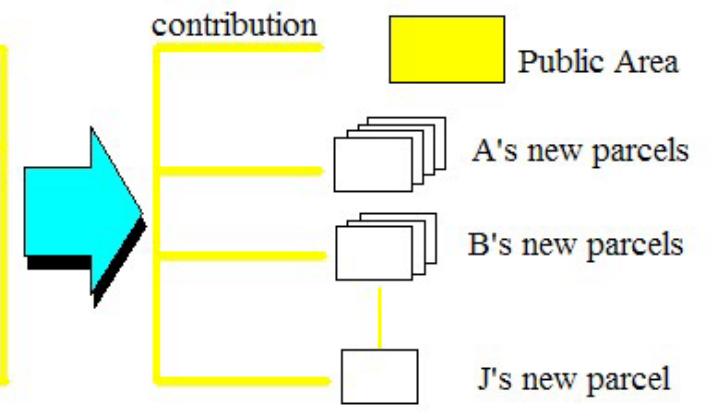

Figure 2; Mechanism of Land Readjustment, (Yomralioglu, 1993) 


\section{Practice of Urban Land Readjustment in Egypt}

In the Egyptian case, land readjustment was part of the Urban Planning Law No.3 of 1982. Article 19 of the law cited the integration of parcels and their redistribution as a means to facilitate subdivision. Also, the law permitted expropriation in case a minority of landowners disagrees with the land readjustment proposal. Yet, it is unclear on which scale and how successful land readjustment was implemented. The new building law of 2008 though does not mention land readjustment explicitly although this seems promising to overcome the problem of fragmented landownership as the Egyptian case.

The UN Habitat team conceived land readjustment as a form of governance that offers room for high levels of participation which facilitates planning without eviction or expropriation. Instead of a top-down planning process and a reality of informal encroachments, land readjustment brings landowners, tenants, NGOs, planners, city officials and government authorities together, ensuring an inclusive and efficient planning process. In this sense, land readjustment shapes urban legislation, facilitates urban planning and bears the possibility to utilize land as a revenue source to finance basic services and infrastructure. Thereby, the cultural context should be taken into consideration.

In the Egyptian context, land is of extreme importance to people and there is a strong sense of ownership. This is why the idea of land pooling is in general is not easy to be applied in the Egyptian context. Landowners are keen to keep their original plot as far as possible and do not accept land to value exchange models of land readjustment. Additionally, the fact that landowners have no trust at all in the state means that landowners refrain from entrusting their land to somebody else which is why land pooling and land to value is impossible in the Egyptian case. 


\section{Land readjustment Online Evaluation Platform (LR.org, 2018)}

The critical components of an evaluation framework; in means of good practices were analyzed for the objective of providing an objective basis from the successful implementations and experience. this online evaluation framework platform; almost all ISI journal articles on LR were analyzed which are; (Agrawal, 1999; Archer, 1992; Çete, 2010; Robert Home, 2007; Rob Home, 2007; Hong and Needham, 2007; Karki, 2004; Larsson, 1997; Li and Li, 2007; Lin, 2005; LR.org, 2018; Mathur, 2013, 2012; Sorensen, 2000; Turk and Korthals Altes, 2010b, 2010; Van Der Krabben and Needham, 2008)

\subsection{Policy level}

A policy is the expression of principles or plan of actions used to reach definite long-term goals, it is divided into four main sections as follows; (Yilmaz et al., 2015).

\section{Land policy aspects}

$\circ$ Land policy is about the measures that will be taken by the governments on

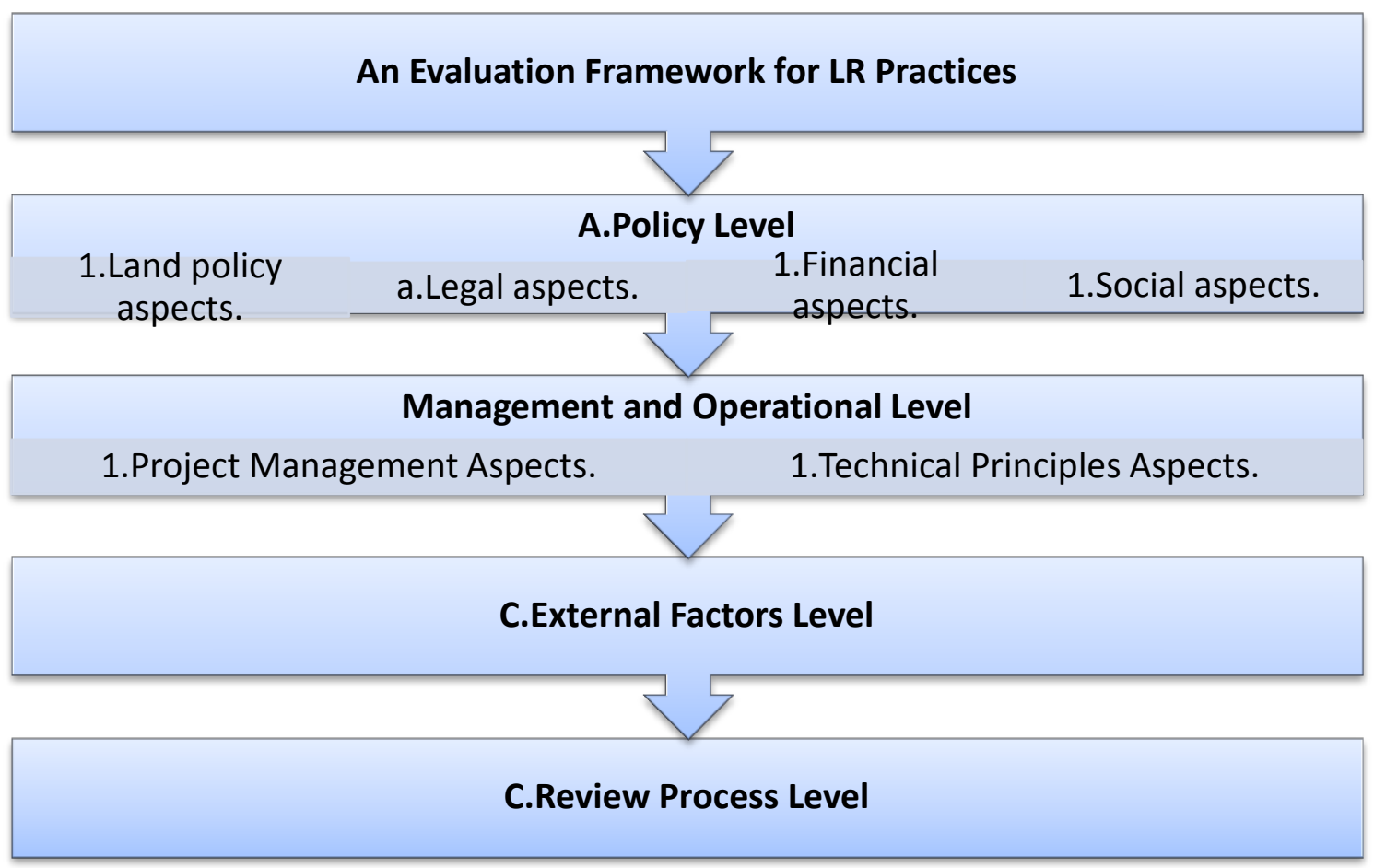

Figure 3, Land Readjustment Evaluation Platform Model, (LR.org, 2018)

major issues such as land administration, land use and land management. (Yilmaz et al., 2015).

\section{Legal aspects}

○ The legal aspect in policy level focuses on the legal principles that create a 
legal basis for institutions governing land, and sets out the rules for land policies, land rights and all land-related activities, that can be considered as a term of land management (Yilmaz et al., 2015).

\section{Economic and financial aspects}

- Economic and financial aspect in policy level is in the responsibility of the governments. It focuses on the economic and financial policies and principles that aim to provide a self-financing technique for urban land and infrastructure development.

\section{$\underline{\text { Social aspects }}$}

- The social aspects in LR focus on the policies, principles, legislation and activities such as encouraging the participation of landowners in the process, ensuring transparency in project phases and ensuring fairness and equality. Consequently, the duration of LR can be extended. Sometimes, the outcomes of the annulments can block the whole LR process (LR.org, 2018).

\subsection{Management and operational level}

The management of the LR studies can be either private or public initiative. The stakeholder's responsibility is to govern and operate the projects which involve preparation, management and realization of the projects. (LR.org, 2018; Yilmaz et al., 2015), it is divided as follows;

\section{Project management aspects}

- Management of the LR projects requires knowledge and experience in both technical terms and management. Resources and experts in the field of project management are required. (LR.org, 2018).

\section{Technical principles aspects}

o These aspects are concerned with the technical aspects of the management and operation level. These aspects are related to the technical details; such as the feasibility of the area, size and timing of the projects as well as the allocation and structure of the plots (LR.org, 2018).

\subsection{External factors level}

- External factors in the framework have an impact on the evaluation, external factors affect the success of an LR but not directly controlled by the LR organization in terms of capacity building, research and development, technology and data quality (LR.org, 2018; Yilmaz et al., 2015). 


\subsection{Review process level}

The main aim of the review process level is to ensure the sustainable evaluation of the efficiency, limitations and performance of LR processes. (LR.org, 2018).

\section{Land Readjustment in Egypt (The pilot area: El Rezqa area, Banha)}

The pilot area that was selected for land readjustment is located inside an area called El Rezqa area. It is surrounded by four main streets. It is important to note that the area represents a prime location in Banha as it is located in the downtown area of the city close to the Nile. This is why land value and real estate prices in this area are estimated to be very high. Also, this means that the project site will be a residential area for the upper middle class (Tiemeier, 2015; UN-Habitat, 2017, 2015).

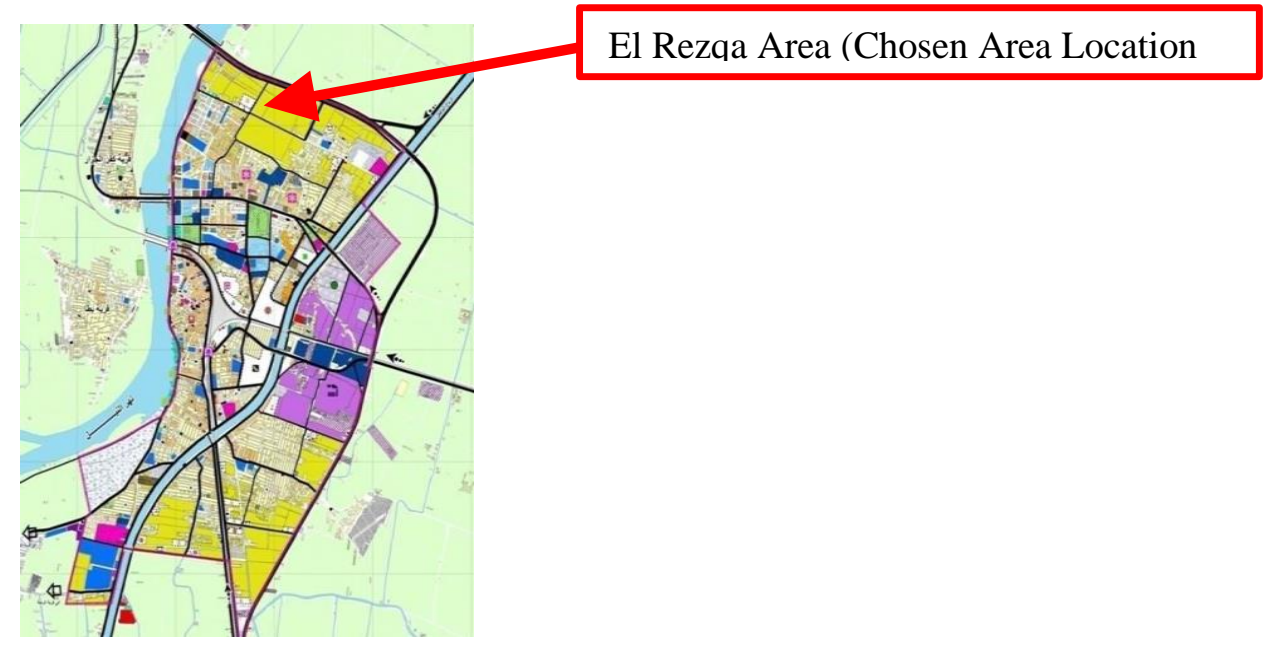

Figure 4, Banha city - General Strategic Plan for Banha City, (Tiemeier, 2015)- (GOPP, 2015)

The detailed planning process for the urban expansion areas was initiated by the GOPP in coordination with the local General Department for Urban Planning and Development in Qalyoubia governorate. Figure 4 presents the proposed detailed plan for one of the expansion areas identified by the strategic plan (Tiemeier, 2015; UN-Habitat, 2017, 2015).

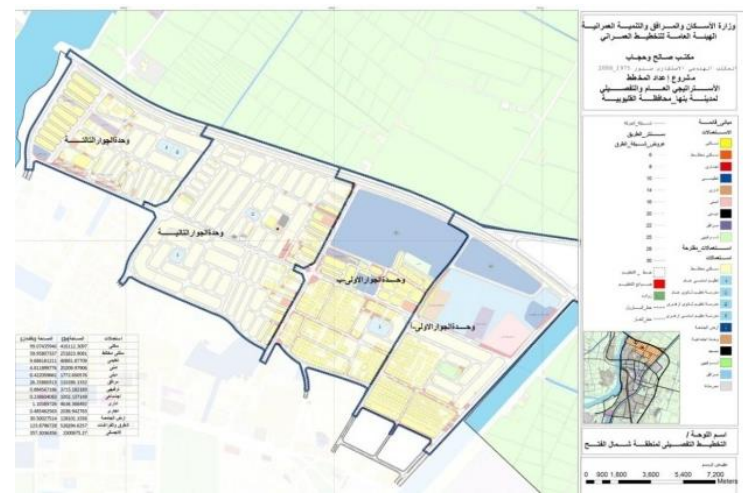

Figure 5, Detailed Plan of northern extension area in Banha, (GOPP, 2015) 


\subsection{Identification of Project's stakeholders}

Project's stakeholders are GDUPD in Qalyoubia governorate in Banha, UN Habitat team, brokers, informal contractors, lawyers, landowners, local administration. the UN team made it clear to all stakeholders that the project would always act in accordance with the laws, especially with the Building Law (Tiemeier, 2015; UN-Habitat, 2017, 2015).

\subsection{Identification of landowners and land surveying}

First, all information and documentations were recorded in CAD and GIS format, satellite images of the site from the GOPP. Second, Land Survey Authority (LSA) in Banha was to verification for parcel sizes with the government's cadastral documents. To do this, the team approached the in order to get land subdivision map (Tiemeier, 2015).

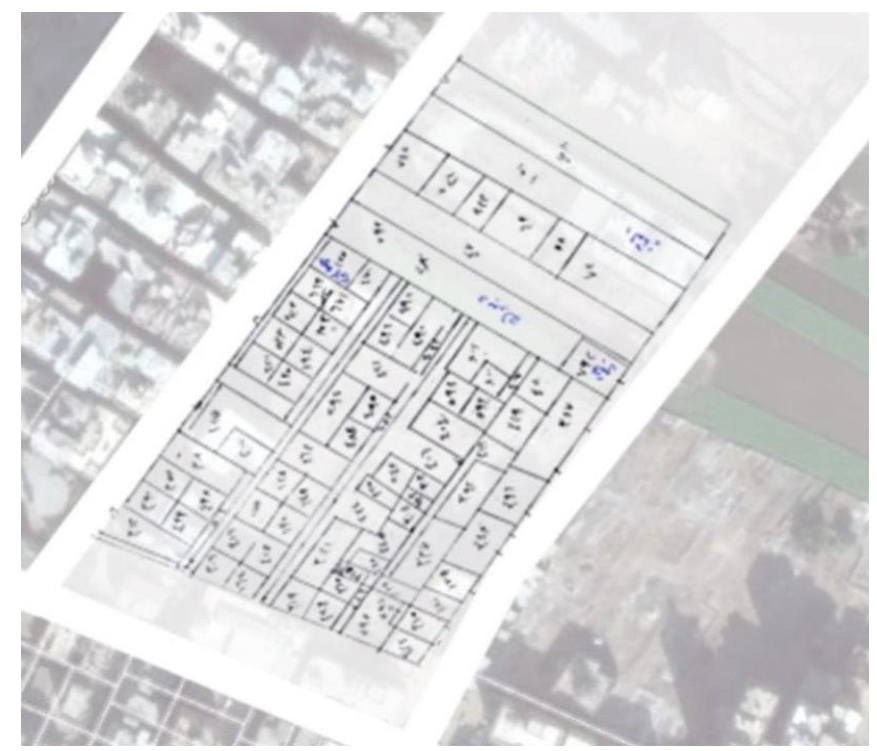

Figure 6, Cadastral map of the site, (UN-Habitat, 2018)

The team had three tools to obtain information: Land parcel mapping based on the team's physical lands' surveys efforts.

a) Land parcel histories based on the information from the REPD.

b) Informal land parcel map from the LSA.

In several meetings with key figures of the landowners, the team tried to bring together the three sources in order to understand the current situation of landownership and plot sizes on the ground. Finally, after about three months, the team was able to create an accurate landownership map as shown in figure 6, (UNHabitat, 2018) . 


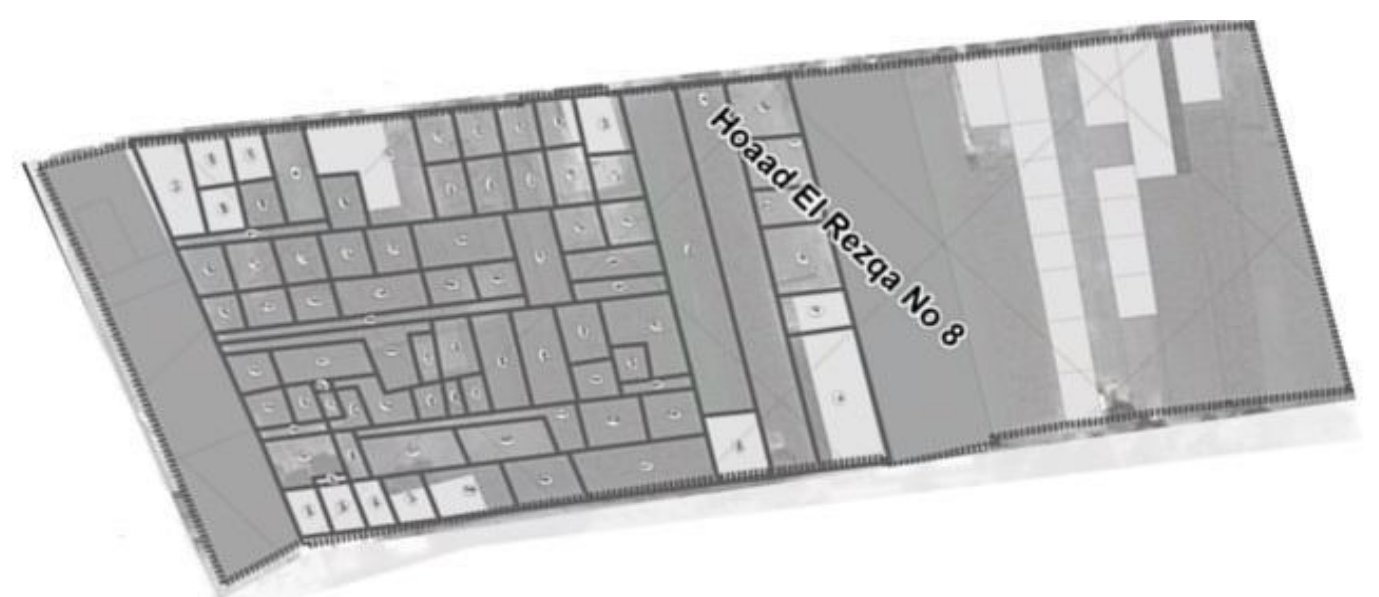

Figure 7, UN-Habitat's landownership map, (UN-Habitat, 2018)

\subsection{Changing landownership of the site}

In an attempt to understand ownership, the team started to hold meetings with the landlords as one of the main characteristics of LR is community / actors' participation the all the processes. In 2009 , land became officially part of the city of Banha, the land changed from agricultural to building land. After that, land ownership got even more fragmented and sold in meter before planning with the tendency to a further rise in its financial value. Highlighting major events during Planning Phase after Jan, 2011 Revolution, based on the UN Habitat, in 2011, some of the land had been given an official approval to be subdivided, it was subdivided would be considered illegal according to BPL119 (Building Law, No. 119, 2008; Tiemeier, 2015).

\subsection{Designs}

To make planning guidelines transparent, the UN Habitat team and the landowners signed an agreement including the following planning (Building Law, No. 119, 2008; Tiemeier, 2015):

- All landowners would give up the same percentage of their land for roads and services according to the BPL 119 (equity).

- In reassigning a plot of land to a landlord, the team would do its best to make sure it would be at the closest physical proximity to that of the landlord's original site.

- The team would also respect any specific advantages that a parcel had and make sure the new parcel provided also those advantages.

- The minimum land size of a parcel will be 120 square meters / street $10 \mathrm{~m}$.

\section{Governmental detailed plan}

After extension areas of the city were identified in the Strategic Plan for Banha city, a consultant hired by the GOPP worked on detailed plans for those areas which were approved in 2014 (GOPP, 2015, 2015; Tiemeier, 2015; UNHabitat, 2017). 


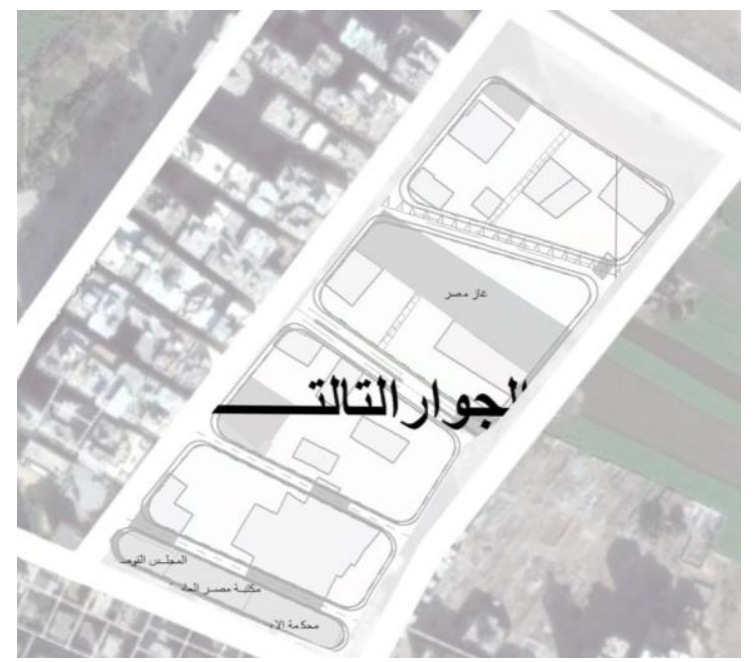

Figure 8, Governmental Detailed Plan, (Tiemeier, 2015)

There was many Challenges with governmental detailed plan. Superblocks were not respecting size of existing plots. Unclear, how street network will be implemented taking into consideration land ownership. Plan is not taking into consideration landowners' needs as it is a top-down planning process which makes it likely that the plan will be ignored by landowners.

\section{Landowners' subdivision plan}

The following plans below represent the efforts by the landowners to subdivide their site. With reference to the UN Habitat reports It consisted of 40 land parcels varied in size between 120-450 square meters. The total area allocated for road network was around $31-35 \%$ of the total area of the site. the Main Challenge was that we could not get all of the landowners' agreement on the LR proposal (Tiemeier, 2015).

\section{Final adjustment plan}

After further discussions with the landowners, the UN Habitat team proposed another possible subdivision plan that found large support among landowners (GOPP, n.d.; Tiemeier, 2015).
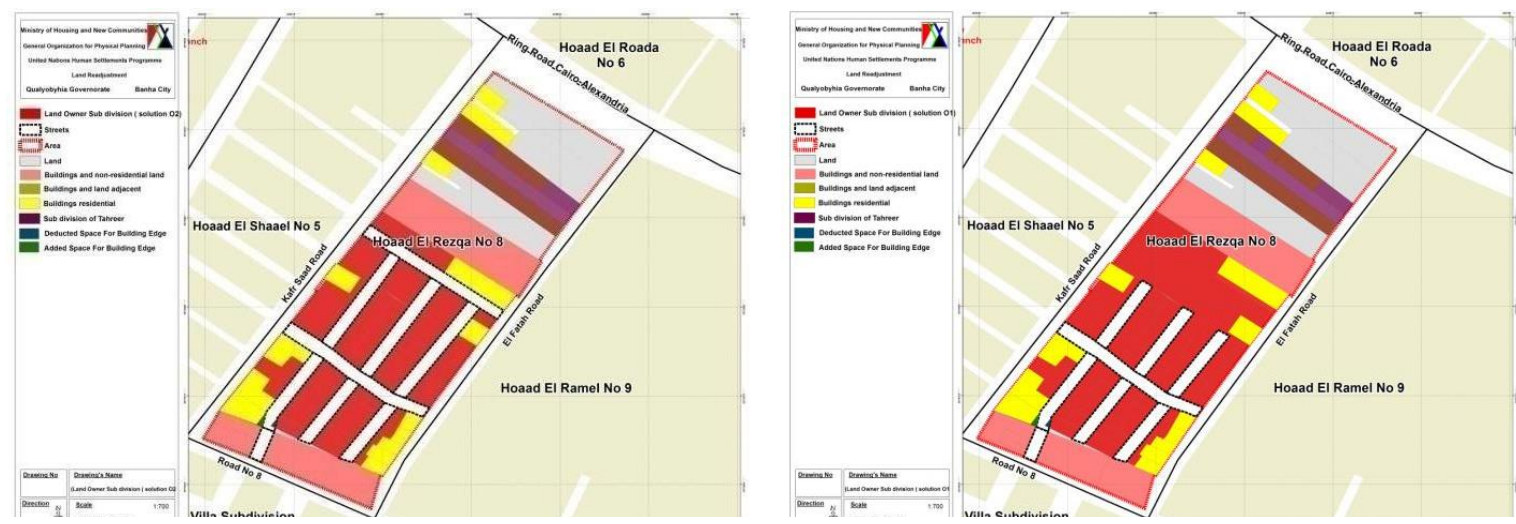

Figure 9, Landowners' Subdivision Proposals (LR Plans), (GOPP, 2015; Tiemeier, 2015) 


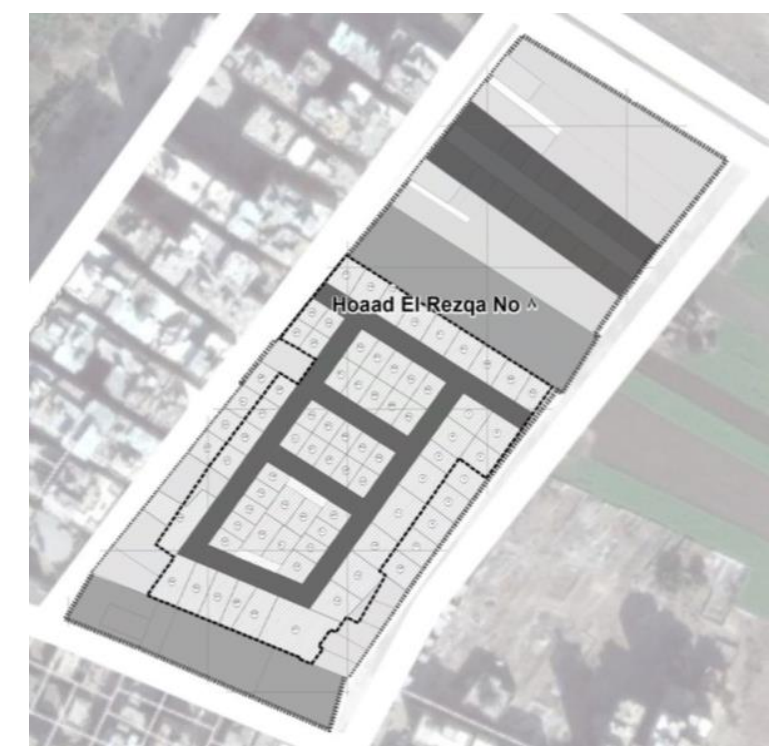

Figure 10, UN Habitat's subdivision plan after discussion with landowners(UN-Habitat, 2016)

Land readjustment was thus not only a way to implement infrastructure and a street network but also to create buildable plots. To make sure of the implementation of the plan gained through land readjustment, here comes building permits and the Real Estate Publicity Department for the registration time to reidentify landowners after final readjustment plan implementation.

Since the project was successful as an end result, the paper after going through El Rezqa Area as a casestudy, it also used the LR Assessment platform that was mentioned before for Banha Case Study, to measure how far can this platform help in assessing the feasibility of any selected area to use LR as an upgrading or development method. Since The aim of "LR.org" is to contribute to the understanding of LR and raise the awareness of an internationally accepted evaluation and monitoring methodology, which includes developing the awareness, a vision and strategies through institutional development, legislation and coordination of stakeholders under the different aspects of LR.

In accordance to An Evaluation Framework for LR Practices, El Rezqa Area. First, on the policy level, LR was included in Land policies, Land speculation should be prevented in during implementation of LR. Sadly, as Egypt is a developing country LR was not simple to be understood and but it was quick enough to improve its success once it was explained. LR final plans were in conjunction with the final cathedral plans on the contrary in the beginning where updated data was missing. After the agreement from all project's stakeholders LR was realized systematically and sanctions was clearly defined. Design team made sure of that, the allocation base can ensure equality and fairness. In conclusion plan of actions were used to reach definite long-term goals that considered measures that can be taken by the governments on major issues such as land administration, land use and land management. 
Accordingly, base of legal principles was available due to state support that created a legal basis for institutions governing land, and has set out the rules for land policies, land rights and all land-related activities. With the help of experts and professional and in the presence of community participation self-financing technique was provided for urban land and infrastructure development. The social aspects were defined throughout LR as it focused on the policies, principles, legislation and activities such as encouraging the participation of landowners in the process, ensuring transparency in project phases and ensuring fairness and equality. To highlight how important Social aspect is, the whole LR process can be blocked in case of any annulments for any of the stakeholders. According to UN Habitat Report, 2017 Egypt improved three policy areas of decentralization, including finalization of a detailed plan under the pilot project on Land Readjustment in Banha (UN-Habitat, 2017). In which, Transformation of urban law, over a two-year period, from 2014 to 2016, significant changes were achieved in transforming the following four key urban laws (UN-Habitat, 2015):

- Building Law No. 119 of 2008 which governs land use, land subdivision, and development of land (UN-Habitat, 2015).

- A new Planning Law was drafted to replace the outdated law No. 70 of 1973. The new law includes land value sharing instruments such as the betterment levy which helps to generate municipal revenue for planning (UN-Habitat, 2015).

- The Government of Egypt approved a Unified Planning Law in December 2017 (UN-Habitat, 2015).

- The Ministry of Housing developed a law for urban (UN-Habitat, 2015).

Concluded Land Readjustment Egyptian Framework can be summarized as follows;

\begin{tabular}{|c|c|}
\hline $\begin{array}{l}\text { Project Area's Selection } \\
\text { (Planning) }\end{array}$ & $\begin{array}{l}\text { - Determination of the project area } \\
\text { - Approval of the project by the city council } \\
\text {-Announcement of the project }\end{array}$ \\
\hline $\begin{array}{l}\text { Define the boundaries of the } \\
\text { project area (Design) }\end{array}$ & $\begin{array}{l}\text {-Announcement of the project } \\
\text { - Project's Limits and areas Verification } \\
\text { - Land Owner identification } \\
\text { - Survey of the project area, boundaries }\end{array}$ \\
\hline $\begin{array}{l}\text { Establishment of the } \\
\text { implementing body (Design) }\end{array}$ & $\begin{array}{l}\text { - Completion of detailed plans } \\
\text { - Determination of land characteristics } \\
\text {-Drawing the implementation plan } \\
\text { - Re-examination of land records }\end{array}$ \\
\hline
\end{tabular}




\begin{tabular}{|c|c|}
\hline Draft plan of public facilities & $\begin{array}{l}\text { - Calculation } \\
\text { - Subdivision layout } \\
\text { - Exchange, division, and consolidation of } \\
\text { land } \\
\text { - Land distribution } \\
\text { - Compilation of records on distribution } \\
\text { - Compilation of replotting plan } \\
\text { - Submissions of reports to the authorities } \\
\text { - Approval of the reports } \\
\text { - Announcement of replotting plan }\end{array}$ \\
\hline Consent of landowners & $\begin{array}{l}\text { - Hearing objections } \\
\text { - Notification to landowners } \\
\text { - Making final corrections }\end{array}$ \\
\hline $\begin{array}{l}\text { Approval of replotting design incl. } \\
\text { financial plan, project } \\
\text { implementation plan, land } \\
\text { contribution }\end{array}$ & $\begin{array}{l}\text { - Demarcation of new boundaries } \\
\text { - Drawing of cadastral map }\end{array}$ \\
\hline Replotting works & - It includs construction of public facilities \\
\hline Registration of new land rights & $\begin{array}{l}\text { - Re-plotting resulted into new plots varies in } \\
\text { sizes }\end{array}$ \\
\hline Distribution of new land titles & $\begin{array}{l}\text { - Making sure that landowners get their land's } \\
\text { rights and compensation if needed }\end{array}$ \\
\hline $\begin{array}{l}\text { Financial balancing (adjustment) of } \\
\text { the project }\end{array}$ & $\begin{array}{l}\text { - financing the project through the percentage } \\
\text { given via land owners }\end{array}$ \\
\hline Final reports & $\begin{array}{l}\text { - financial reports } \\
\text { - Land Rights and outline identification } \\
\text { - State approvals }\end{array}$ \\
\hline $\begin{array}{l}\text { Land Readjustment } \\
\text { Implementation on the selected } \\
\text { area }\end{array}$ & - applying the final LR final approved Plan \\
\hline
\end{tabular}

Figure 11; LR Egyptian Framework, (By the Researcher)

UN Habitat played an important role on the management and operational levels as one of the project's stakeholders. The state's responsibility was to govern and facilitate the operation of the project. While, UN Habitat played an important role in preparation, management and realization of the project to a successful manner. 
Management of the LR projects requires knowledge and experience in both technical terms and management. Resources and experts in the field of project management and technical knowledge and experience were project's stakeholders, in means of technical details; such as the feasibility of the area, size and timing of the projects as well as the allocation and structure of the plots. Finally, External factors were present in the very first period of LR implementation discussions in Egypt, in which Revolution Jan,2011 has an impact on the process, meanwhile, it only extended the project duration only. Lastly, LR M in an Egyptian context was concluded as previously shown in Figure 11.

\section{Conclusion}

Land readjustment is an essential tool used for the re-organization of urban areas. It aims to convert cadastral parcels into suitable forms of development plots for public and private use according to town planning requirements. Hence, land readjustment method maintains great opportunities to the solution of land-use problems in urban-fringe areas in means of controlling informal areas creation. (Konursay, 2004).

Land readjustment projects are plane-oriented development projects that change the form or nature of land to improve public facilities (roads, parks, etc.) and to promote housing land use within city planning areas. Projects in this category are utilized as a typical method for urban development, which enables comprehensive development of public facilities and housing land, and town development corresponding to many purposes depending on local characteristics.

land readjustment projects' stakeholders varies from project to another depends on the nature and size of the area, if the stakeholders are: individuals, land readjustment associations, land readjustment companies, prefectures and municipalities (local governments), Consultants and regional public housing corporations, local governments, the Ministries, public housing corporations, then projects shall be executed within the areas that were set forth in city plans in terms of the land readjustment projects because these projects are to be executed as city planning projects. On the other hand, when land readjustment projects' stakeholders are individuals, land readjustment associations and companies, projects shall be executed without city planning decisions except in cases where these projects are governmentally subsidized.

Land readjustment is a powerful land management tool which provides great opportunities for local authorities when public and private land is needed for urbanization. It is the process of exchanging raw land for serviced land, and therefore can easily be suited to countries where governments have difficulty to acquire land for public and private requirements, although land readjustment is a very effective land planning process in controlling urbanization some technical issues limit the performance of land readjustment procedures. 
land readjustment was efficiently implemented in Al Rezqa area pilot Egyptian project, as it played an important role in securing a fully-serviced urban development without direct public funding, Land for public purposes and physical infrastructure being paid for is from the shared profits of the development, while, The land-owners participate in the profits and meet their wider social obligations while providing for themselves an area that has adequate services and infrastructure which raised their lands' value after the LR implementation.

\section{References}

[1] Agrawal, P., 1999. Urban Land Consolidation: A Review of Policy and Procedures in Indonesia and Other Asian Countries. Geoj. (C) 2000 Kluwer Acad. Publ. Print. Neth. 49, 311-322. https://doi.org/10.1023/A:1007150828772

[2] Archer, R.W., 1992. Introducing the urban land pooling/readjustment technique into Thailand to improve urban development and land supply. Public Adm. Dev. 12, 155-174. https://doi.org/10.1002/pad.4230120204

[3] Building Law, No. 119, 2008.

[4] Çete, M., 2010. Turkish land readjustment: good practice in urban development. J Urban Plan Dev 136, 373-380.

[5] David Sims, 2003. UN-Habitat Global Report on Human Settlements, The Challenge of Slums (Case Studies for the Global Report). UN Habitat, Earthscan, London.

[6] De Souza, F., Ochi, T., Hosono, A., 2018. Land Readjustment: Solving Urban Problems Through Innovation.

[7] Doebele, W.A., 1987. The evolution of concepts of urban land tenure in developing countries. Habitat Int. 11, 7-22.

[8] Doebele, W.A., 1982. Introduction and Synopsis in Land Readjustment. Lexington Books, Lexington, MA.

[9] GOPP, 2015. Detailed Plan of northern extension area in Banha. الادارة الهندسية بالوحدة المحلية ل URL https://scontent.fcai3-2.fna.fbcdn.net/v/t31.08/11894004_1673997016152356_7134195934984471018_o.jpg?_nc_cat=110\&_nc_oc=AQ lavXUgytisuYH6G3Ishr6wvX-a4DbKEzLgXEGbuf1SKbxLmuyo2dQ69BZKmHk3nw\&_nc_ht=scontent.fcai32.fna\&oh=afc977c16d7ea2aee770064232944364\&oe=5DC7798B (accessed 8.29.19).

[10] GOPP, n.d. GOPP [WWW Document]. الهيئة العامة للتخطيط العمراني. URL http://gopp.gov.eg/gopp-establishment/ (accessed 8.29.19).

[11] Hein, C., 2010. Shaping Tokyo: Land Development and Planning Practice in the Early Modern Japanese Metropolis. J. Urban Hist. - J URBAN HIST 36, 447-484. https://doi.org/10.1177/0096144209347737

[12] Home, Robert, 2007. Land Readjustment as a Method of Development Land Assembly: A Comparative Overview. Town Plan. Rev. 78, 459-483.

[13] Home, Rob, 2007. Land readjustment as a global land tool: focus on the Middle East.

[14] Hong, Y., Needham, B., 2007. Analyzing Land Readjustment: Economics, Law, and Collective Action. Lincoln Institute of Land Policy, Cambridge.

[15] Karki, T., 2004. Implementation experiences of land pooling projects in Kathmandu Valley. Habitat Int 28, 67-88.

[16] Konursay, S.Y., 2004. Land readjustment process in urban design: project management approach. Izmir Institute of Technology.

[17] Larsson, G., 1997. Land readjustment: A tool for urban development. Habitat Int. 21, 141152. https://doi.org/10.1016/S0197-3975(96)00059-8

[18] Li, L.-H., Li, X., 2007. Land Readjustment: An Innovative Urban Experiment in China. Urban Stud. 44, 81-98. https://doi.org/10.1080/00420980601023844

[19] Lin, T.-C., 2005. Land assembly in a fragmented land market through land readjustment. 
Land Use Policy 22, 95-102.

[20] Lozano, E., J-P, P., Mataix-Solera, J., Arcenegui, V., Bárcenas-Moreno, G., González-Pérez, J., García-Orenes, F., Torres, M.P., Mataix-Beneyto, J., 2013. Biological and chemical factors controlling the patchy distribution of soilwater repellency among plant species in a Mediterranean semiarid forest.

[21] LR.org, 2018. LR.org [WWW Document].

[22] María del Carmen, P., 1992. Settlement Patterns in Unplanned Areas: Case Study San José de Chirica, Ciudad Guayana, Venezuela. McGill University, School of Architecture.

[23] Mathur, S., 2013. Use of Land Pooling and Reconstitution for Urban Development: Experiences from Gujarat, India. Habitat Int, Elsevier Ltd 38, 199-206. https://doi.org/Habitat International 38

[24] Mathur, S., 2012. Self-financing urbanization: insights from the use of town planning schemes in Ahmadabad, India. Cities 31, 308-316.

[25] Molen, P. van der, 2013. Land Readjustment (alternative wording: land pooling, land reassembly, land replotting, land reparcellation, land repartition....).

[26] Motala, S., 2002. Organizing in the Informal Economy: A Case Study of Street Trading in South Africa (SEED WORKING PAPER No. No. 36), Series on Representation and Organization Building. International Labour Office, Geneva.

[27] Sorensen, A., 2000. Land readjustment and metropolitan growth: an examination of suburban land development and urban sprawl in the Tokyo metropolitan area. Prog. Plan. 53, 217-330. https://doi.org/10.1016/S0305-9006(00)00002-7

[28] The Local Government and Municipal Knowledge Base, 2018. Trunk Infrastructure - LGAM Knowledge Base [WWW Document]. URL http://gam.wikidot.com/trunk-infrastructure (accessed 10.6.18).

[29] Tiemeier, V., 2015. Documentation of a pilot project on Land Readjustment in Banha-City.

[30] Turk, S.S., Korthals Altes, S.W.K., 2010b. Potential application of land readjustment method in urban renewal: analysis for Turkey. J Urban Plan Dev 137, 7-19.

[31] Turk, S.S., Korthals Altes, W.K., 2010. How suitable is LR for renewal of inner city areas? An analysis for Turkey. Cities 27, 326-336.

[32] UN Habitat [WWW Document], n.d.

[33] UN-Habitat, 2018. Egypt Urban Issues [WWW Document]. URL https://unhabitat.org/egypt/urban-issues/ (accessed 10.1.18).

[34] UN-Habitat, 2017. Annual Progress Report 2017, United Nations Human Settlements Programme (UN-Habitat). UN-HABITAT.

[35] UN-Habitat, 2015. Annual Progress Report 2015. UN-HABITAT.

[36] Uzun, B., 2009. Using Land Readjustment Method as an Effective Urban Land Development Tool in Turkey Journal. Surv. Rev. 41, 57-70. https://doi.org/10.1179/003962608X390003

[37] Uzun, B., Yomralioglu, T., Inan, H.I., Aydinoglu, A.C., 2009. Evaluation of initiatives for spatial information system to support Turkish agriculture policy. Sci. Res. Essays 4, 15231530.

[38] Van Der Krabben, E., Needham, B., 2008. Land readjustment for value capturing: a new planning tool for urban redevelopment. Town Plannning Rev. 79 (November).

[39] Van der Molen, P., 2015. Rapid urbanisation and slum upgrading: What can land surveyors do? Surv. Rev. 47, 231-240.

[40] van der MOLEN, P., 2014. Engaging the Challenge of Rapid Urbanization and Slum Upgrading and Enhancing the Role of Land Surveyors. FIG Peer Rev. J.

[41] Yilmaz, A., Çağdaş, V., Demir, H., 2015. An Evaluation framework for land readjustment practices. Land Use Policy 44, 153-168. https://doi.org/10.1016/j.landusepol.2014.12.004

[42] Yomralioglu, T., Bayram, U., 1996. Land readjustment implementations in Turkey. 


\section{Table of Figures}

Figure 1, An Illustration of LR Process, (YAU, 2009) 64

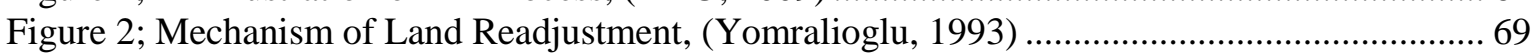

Figure 3, Land Readjustment Evaluation Platform Model, (LR.org, 2018)................................... 71

Figure 4, Banha city - General Strategic Plan for Banha City, (Tiemeier, 2015)- (GOPP, 2015)... 73

Figure 5, Detailed Plan of northern extension area in Banha, (GOPP, 2015) ................................. 73

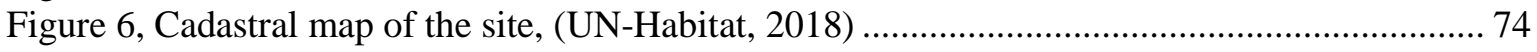

Figure 7, UN-Habitat's landownership map, (UN-Habitat, 2018) ................................................ 75

Figure 8, Governmental Detailed Plan, (Tiemeier, 2015) .......................................................... 76

Figure 9, Landowners' Subdivision Proposals (LR Plans), (GOPP, 2015; Tiemeier, 2015)............ 76

Figure 10, UN Habitat's subdivision plan after discussion with landowners(UN-Habitat, 2016) ... 77

Figure 11; LR Egyptian Framework, (By the Researcher)............................................................. 79

\section{List of Tables}

Table 1, Land Readjustment Definitions (By the Researcher) 